\title{
Beyond fish as commodities: understanding the socio-cultural role of inshore fisheries in England
}

Matt Reed \& Paul Courtney, The Countryside and Community Research Institute.

Julie Urquhart, The University of Greenwich.

Natalie Ross, Newcastle University.

Corresponding Author

Dr Matthew Reed

The Countryside and Community Research Institute

Oxstalls Campus

The University of Gloucestershire

Gloucester

GL2 9HW

Matthew.Reed@uwe.ac.uk

\begin{abstract}
Inshore fishing, by boats under 10 metres, has a long tradition on the coasts of England but its role in the contemporary communities is not well understood, and increasingly policy makers have become focused on trying to find ways to improve its environmental, social and ecological sustainability. This paper reports on a research project that sought, through case studies on the English coast, to explore the socio-cultural role that inshore fishing plays and how policies could be developed to enhance its contributions. Inshore fishing was found to be highly valued not only for its importance in supporting livelihoods, but also in the creation of place identities tied to fishing as an occupation and the ecological opportunities for fishing that are available at the different localities. Findings are discussed in the context of harnessing these attributes for fostering sustainable fishing communities, underpinned by strengthening the ties between the catch and the locality.
\end{abstract}

Keywords

- Social Impacts

- Occupational Culture

- Tourism and Fishing

- Social Sustainability

- Governance. 
Highlights

- The importance of inshore fishing to those living in coastal communities.

- The ways in which fishing is incorporated in local cultures and the economy.

- How policy impacts on the shaping of the social aspects of fishing and its societal impacts.

\section{Introduction}

Interpreted in a certain way contemporary biology is, somehow, a philosophy of life. [1:319]

American neo-liberalism seeks rather to extend the rationality of the market, the schemes of analysis it proposes, and the decision making criteria it suggests to areas that are not exclusively or not primarily economic [2:79].

In a paper in Science John Beddington and his colleagues considered the challenges being faced by fisheries and how there are successful examples of management from a range of international contexts, their contribution typifying many discourses that have become common in the discussion of fisheries [3]. In their global tour the authors recognised the need to include not only the biological sciences but also the social sciences, although this is largely framed in economic terms. In common with many policy makers, the policy suggestions and the broader discourse of fisheries conservation in their paper are imbued with models and assumptions that point to a particular bio-politics where fish populations are the locus of governance. Fishermen are seen as being controlled by economic incentives based on allocated rights and in need of a strong authority capable of constraining their efforts. Increasingly, these suggestions are characterised by neo-liberal ideas whereby conservation can be assured through regulating the activities of fishermen who have rights to common property in order to create a market in which fish are correctly valued and thereby conservation will be attained, backed up by robust sanctions if needs be. These sanctions have become the locus of contemporary fishing policy.

Comprehensive fisheries policy and management systems were only established in the last 30 - 40 years, in response to growing concerns about the depletion of commercial fish stocks through overfishing [4], after claims that much ecological damage had already been done to fisheries [5]. The stated priority was to halt the depletion of fish stocks, allow recovery and create a sustainable resource, although the European Union's Common Fisheries Policy 
(CFP) was also concerned with equal access to the resource between member states [6]. Simultaneously national governments, particularly those with a tradition of sea fishing or the use of fish in national cuisines, had an interest in a successful and resilient commercial fishing industry. With these objectives in mind, most policy and research to date has centred on biological and economic objectives. Measures that have been considered necessary to combat overfishing and preserve a commercial fleet have come at what Symes and Phillipson describe as a 'substantial social cost' for employment and effects on fishing communities, an area which has hitherto been under researched and so lacks an adequate conceptual framework $[4,7]$

The social impacts that Symes and Phillipson allude to above raise a number of questions around the impacts of fishing and fisheries policy not only on employment but how it shapes the lives of those living and working in modern day fishing ports and how it is interwoven with other social and economic activities of communities which are often characterised as much by their rural presence as their coastal influences. This is especially pertinent to the social impacts of commercial fishing by under $10 \mathrm{~m}$ or 'inshore' boats in England, where despite a long tradition, fishing has become economically marginal and domestic fish species are not widely eaten by English consumers. Fishing by under-1om boats is therefore interstitial, not the bulk capacity of deep water fishing that is the locus of policy and commercial attention, but not so inconsequential as to be unimportant to either conservation efforts or the life of the communities interwoven with it. The final interstice is that the fish caught occupies a zone where regional and local food projects encompassing the rural areas of England meet, where fish is either specifically excluded or elided.

In 2009 a research project was commissioned by Defra with the aim of exploring the social impacts of inshore fishing in England. Specifically, the research team sought to expose some of the social, cultural and economic conditions affecting people living and working alongside fishing. Through six case study fishing ports, the research focussed on links that inshore fishing has with the wider community and economy, and in turn the impacts that ensue. Three main themes emerged from the study: the role of fishing in place making, the tensions this has with the traffic in fish as a commodity, and the possibilities of using fish as a tool for sustainable community development, elements of which are described and discussed in this paper. 
To set the context of this exploratory research, the paper begins with a theoretical overview, drawing on debates around neo-liberalism, fisheries policy and rural development. Following a description of the research methods and case study communities, findings from the qualitative interviews are presented, distinguishing between the role of fishing in shaping the lives and identities of host communities and place; the economic and ecological opportunities and the role of inshore fishing in tourism The findings are discussed in the context of harnessing these attributes for fostering sustainable fishing communities, underpinned by strengthening the ties between the catch and the locality.

\section{Theoretical perspectives from rural development}

Within the social sciences there has been a sustained discussion around the social consequences of the contemporary food system, of which fish and shellfish are a subsystem, although the overwhelming focus has been on farming [8-10]. Broadly the production of foods as commodities, which are stripped of provenance and a social history, to either be branded through global corporations or sold as a generic products onto global markets have been seen to be most damaging to producer communities [11, 12]. Increasingly globalised labour markets and individualistic adaptation strategies can result in people from producer communities becoming less and less attached to place. A consequence of this is outmigration and the depopulation of rural areas for financial city centres [13, 14].

Alternatives to the present system have been posited as being through promotion of local foods [15], those based on alternative technologies such as organic production [16, 17], or those whereby the links between producer and consumer are socially if not geographically proximate, generally called short food chains $[18,19]$. These latter alternatives have been promoted not only because they retain a greater amount of the economic value of the product in the producer community but also can be combined with other activities to create greater economic opportunities in the wider community[2o]. Much policy and academic discussion around rural development in England has become focused on the role of food in 
offering a route through which value can be added, captured and retained in rural areas rather than being drawn inexorably along the food chain towards the multiple retailers and out of the locality [9, 21]. Although this has been primarily a farm centred notion of rural development, there are many reasons to believe that this can be extended to many primary producers of other food products [22].

English domestic demand for a narrow range of fish species shapes the UK market, with three of the ten main species dominating; cod, salmon and tuna [23]. The multiple retailers almost exclusively use supply chains covered by certification processes and/or labelling schemes to supply these species, which results in most of the domestic catch from smaller vessels being destined for either export markets, or the domestic wholesale trade. To a large degree the fish supply is bifurcated, with the domestic inshore catch unable to find a way into the multiple retailers and in turn the supermarkets reliant on imported or farmed fish.

The discussions of placed-based food products being used as a locus for rural development has pointed to the social, cultural and environmental gains that can be derived from associating a product with a particular place [24]. This association is neither automatic nor solely the work of marketing but is generally constructed through contentious actions; markets are not made solely through economics but also social and cultural contestations [25]. The products backed through certification schemes, either reflecting a provenance and/or attainment of an environmental standard, can become the vehicle through which economic as well as social and cultural goals can be obtained[26]. In some instances links are formed between these products and tourism so that the food bridges different industries [21]. The bulk of food products may remain commodities traded with associations of place stripped away, but those foods that have a story are providing considerable gains for both producers and communities, such as in Farmers' Markets [19]. As discussed below this has been primarily a process centred on farms and their produce in England, but this project brought these discussions to a new network of stakeholders.

\section{Materials and methods}

The research that this paper draws on took place over a twelve-month period (November 2009 - 2010) and was split into two phases. The first phase involved qualitative research in 
six case study locations across England, namely Amble, Newlyn, Padstow, Rye, Whitby and Whitehaven (see map in Figure 1). Case study sites were selected based on the position of the community on the Index of Multiple Deprivation, the percentage of boats registered in the port that were under 1om, the income derived from fishing per capita and fishing income per boat and to ensure the 6 government regions of England were covered (see Table 1). The funding for this project was provided by Defra (UK Department for Environment, Farming and Rural Affairs), who chose between two short lists to decide on the case study areas. During this phase of the research 90 individuals were interviewed; fishermen, their families, stakeholders in the fishing industry and members of the wider community (see Table 2). A semi-structured interview tool was employed to allow comparisons between the localities, which included a panel of multiple choice questions[27, 28]. Interviewees were chosen because they were deemed to be knowledgeable about the local area and/or fishing industry, or held a position of authority or influence in the social networks of the community, with interviewees often holding overlapping roles. It also included those 'citizens' in the town who expressed opinions on the fishing industry's role in the community or about the community more generally, ranging from community development workers, elected officials, tourism managers and business owners. The interviews lasted between 30 and 60 minutes, and were recorded and transcribed. Each interviewee was given a code number to preserve their anonymity in the published outputs of the project, a reflection on the lack of confidence in the regulators and policy makers. In each case study area one researcher acted as lead investigator, with another member of the team joining them for a shorter period to provide support and to assist in the analysis. Each lead investigator provided an analysis of the case study, which formed part of a metaanalysis conducted using Nvivo 8 qualitative analytic software.

[Table 1]

[Table 2] 
Case study communities are described in Table 3, and a map showing location of the case study ports is provided in Figure 1.

[Table 3]

Ranging from rural to ex-industrial, east and west facing, with the dominant industry being most frequently the seaside tourism industry, these case study ports are largely indicative of the socio-economic processes influencing coastal towns in England.

\section{Results}

4.1 Identity and working culture

Fisher is that the politically correct term for us then? (X1- Padstow).

Those interviewed who made their living directly from inshore fishing were predominantly older men, many in their late 5os, who had often spent their entire career in fishing. Often starting as crew on larger vessels before moving to skippering their own boats, they focused on crabs and lobsters where there are fewer restrictions and higher rewards, or nephrops where there is more quota available. They were 'survivors' in a number of senses, not least because they have remained in fishing despite its decline. Their ability to survive reflects a combination of their life stage, 'know how' of fishing and the opportunities open to them. They tended to run their businesses in 'survival mode', keeping overheads and risks low, whilst not looking to reinvest capital in their business. Generally they are able to manage an uneven income and are embedded within the fishing industry.

We found that inshore fishing has a working class masculine occupational culture, by which we mean that features of it - the physicality, danger, technical competence and determination - are also ideals that are embodied by the fishermen [29]. It was clear in discussing fishing with fishermen that they found certain rewards because it focused on 'male' concerns. The focus on technicalities and on competence is an essential part of this masculine culture, including knowledge of the regulations - if only to disparage most of them. Fishermen have used the determination required for their occupation to survive the decline of the industry - survival against the odds is an affirmation of the fisherman's 
identity. Living up to this gendered ideal is a source of identity and pride to the fishermen, as well as many others in the locality as it affirms what they hold to be distinctive about their community.

Fishing is marked by a great deal of contention, with low levels of trust between those who catch fish and those regulating the industry. These tensions are often about the observations of fishermen regarding fish population levels in contrast to the quota available to them and what they feel is the inflexibility of the system. Catches are often inspected on landing, and inspections at sea are a possibility, the fishermen feel the burden of regulation and conservation falls on their shoulders. These observations are at times based on a critique of the sampling techniques and modelling of fisheries science that lead to the quotas, or a contrast with their experience of fish stocks, as one fisherman expressed it: "there are cod out there, dying of old age!" (X1 - Padstow). From other informants came a condemnation of the willingness of English politicians to trade fish quota for other goals within EU policy or the power of conservation groups with their arguments rarely representing the under 10's. In part this can be seen as a culture where argument and ribbing are part of sociability[30], but also where there are very low levels of trust towards officials and policy. The way in which this contention is expressed relates directly to the working culture of inshore fishing as it focuses more on technicalities and the regulations around the catching of fish, where fishermen believe the locus of power lies rather than with consumers and markets.

In discussion, fishermen demonstrated high levels of solidarity towards one another, cut through but not negated by intense commercial competition. For example, identifying that there are 'rule breakers' in the port but refusing to identify or report them to the authorities; in policy discussions withholding arguments that would disadvantage another group of fishermen; or providing the crew for the volunteer lifeboat. In line with the gendered structure of the industry, for many their prime social connection and identity is around their occupation. It is often their families who play the most direct role in the rest of the community, for example in the Seaman's Mission. The occupational networks of the fishermen play an important role in linking coastal communities. As we explore below, they also play a significant symbolic role for non-fishing community members. 
Interviewees were proud to live where they did and spoke highly of their town's virtues as a community and the physical beauty of where they lived. Discussions commonly revolved around what made their place unique and the good fortune of living in a community that was supportive. The way in which that support was organised and expressed varied widely with voluntary groups, not-for-profit organisations, charities, a range of agencies and authorities as well private enterprises of various sizes playing a role. In Whitehaven, for example, the patronage of the nuclear power industry was important to the cultural life of the town but this was realised through not-for-profit organisations and in Amble, a development trust played a central role. This complex array of local actors reinforces the distinctiveness of a place. The degree and type of support offered by the communities varied widely, but almost all of the interviewees felt that the infrastructure of a community was around them.

In some places you have to be born in the community to be a 'local', with fishermen often playing a particular role in that: "Those in fishing are the locals; the true locals call themselves 'cod-heads'..." (W5 - Whitby). Many people who have lived in these communities for a long time felt that they were part of the community but not in quite the manner that 'true' locals were: "I'm not an outsider but I'm stitched on - only lived here 12 years" (W4 - Whitby). What made each community distinctive was in part linked to the history and tradition of the town, which featured fishing and the relationship with the sea, as a non-fisherman observed: "Whitby people working here tend to come from fishing families, it provides a lot of social cohesion, gives people an identity" (W3 - Whitby). Therefore fishermen played a central role in enacting the link between the present and that heritage, the sea and the land. The rhythms of fishing and the presence of fishermen are part of how the community re-makes its sense of place on a regular basis. This can be through traditional festivals such as in Padstow (see below), or the emerging festival in Whitehaven, but these contributing to making each community consider itself distinct.

At times this process can be posed as a question of local or rural values compared to supposed metropolitan ones, which are generally described as being from 'London': 
It was on the radio the other day, and they said it doesn't matter whether you were born Cornish or not, its whether you believe yourself to be Cornish, and I suppose that means adopting the values...if you bring London values and you try to enforce them then you'll never fit in. It's the pace of life and the way you treat other people, don't get too excited about things, it'll happen! ( $\left.\mathrm{N}_{2}-\mathrm{Newlyn}\right)$

'London' therefore takes on the double burden as being the location from which the widely resented regulation of fishing is enacted and also the symbol of a metropolitan culture different to the local one. Many of the interviewees would have disagreed that being a 'local' is a set of values, but there is a correspondence between the belief in a particular place's virtues and the community sharing a set of values or norms. In Padstow fishermen were at the centre of the local mumming festival the 'Obby Oss ${ }^{\text {‘ }}$ and in the town there was a sense that to be a local one had to be born in the town, this was re-enforced by the large number of holiday homeowners. As one fishermen explained about the robust attitude of locals towards the wealthy 'incomers': "We 'ad $f^{\star *} \mathrm{k}$ all 'fore they found us, and we'll have $\mathrm{f}^{\star *} \mathrm{k}$ all when they're gone, but we don't mind" (P4- Padstow). Whilst local identity could be exclusive, interviewees argued that it also created social cohesion.

Another way of asserting the uniqueness of community and building a sense of cohesion is local rivalry. As one interviewee said, after commenting on the polarisation of the Whitby community: "The only thing that unites Whitby is opposition to Scarborough" (W4 Whitby). The use of Padstow as an example of a route that they would not like Newlyn to follow was frequent from interviewees there:

For instance like Padstow, where it becomes a bit celebrity and then [fishing] slides down and takes a back row. And round here, because it is a working fishing port it has that slightly grubby air, which is no bad thing, a working place. If you could click your fingers and go to Padstow from here, both fishing ports on paper but you would think, what's happening here? Everything's upmarket ( $\left.\mathrm{N}_{1}-\mathrm{Newlyn}\right)$.

Here the speaker bundles local rivalry, the decline of fishing, class differences and the influence of 'London' into a package, Padstow might be wealthier but Newlyn remains the centre for 'real' fishermen. This loyalty to the hometown as a primary source of identity was important in most of the case studies and coloured willingness to emulate local rivals/examples. The reverse of this is that more distant examples carry less local rivalry, so

\footnotetext{
1 The Obby Oss (Hobby Horse) is an ancient fertility held on the $1^{\text {st }}$ of May every year. Locals are members of different Oss by family tradition either Red or Blue, each Oss processes through the town accompanied by traditional music and ritual dancing. These processions are followed by revelry throughout the day and long into the night.
} 
Cornish fishermen looked on Northumbrian conservation measures favourably, whilst Devonian merchants were considered better than local ones - in the north of England.

\subsection{Economic and ecological opportunities}

The under 10 metre fleet is hanging by a thread on lobster and crab, there's nothing else to turn to ( $\mathrm{W}_{3}-$ Whitby).

Its not just the regeneration of a fishing port anymore, it's the regeneration of a fishing community with no economic hinterland. You've got a port with a flat area which is the harbour, everything else is on the hill and the only industry down here is fishing. So that's upstream or downstream from the catching sector so the fishing represents 482 jobs in this ward....(N1 Newlyn]

Inshore fishing remains reliant upon the ecological opportunities and species available locally, as mediated by the quota and this has a pronounced impact on the businesses that fishermen can operate. Access to shellfish, particularly species such as brown crab that are consumed domestically opens a different set of opportunities than those that only have an export market such as for spider crab. Our interviews demonstrated that inshore fishermen have three principal routes to market, the most widespread being to sell their catch to fish merchants who then take it to market. Often fishermen do not have access to auction markets and many merchants offer the money immediately for the catch, improving the cash flow of the fishermen. Where they have access to a quayside market, the fishermen use it. The third route is direct sales into commodity fish markets on the Continent; this is most common in prawns and species not eaten in the UK, where the provenance of the fish is deemed unimportant.

Although some fish retains its provenance this represents a very small volume of the catch. In Padstow, which has a very prominent stake in gastronomy, some of the fish is sold directly into the restaurant trade with the catch travelling the few tens of metres from the quayside to the doors of the caterers. Much of the fish not caught locally to Padstow is sourced from Newlyn, so although not specific to the town it is from the same County, with the delivery vans displaying the source of their cargo very visible in the centre of the town. When fish is sold into continental markets its provenance is generally lost. Some of the scallop catch from Rye carries that provenance when it is on sale in France but this was the 
only example in our case studies. In the north of England local sales are even more unusual with one fisherman attempting to sell directly from his boat requiring specific permission from the harbour authorities as previously it was prohibited. The gap between the inshore trade and the supply chains that are tied to the multiple retailers is apparent in that both Whitehaven and Amble have fish processing factories within the town, with the former handling only imported fish and the latter only nephrops.

4.4 Fishing and tourism

Tourists like to see the fish being landed and the fish market (W1o - Whitby). For many of these communities, tourism has become the major source of income, and the most immediate route for improving their economic fortunes. This reality is often based on a community development approach of starting from the 'assets' that the area has - a seaside location, a harbour and the heritage to appeal to visitors. Interviewees were proud of their communities, viewing them as generally supportive, with a unique culture and ambience. Many fishermen, together with those who are involved in running the harbour side, report the draw of fishing for visitors to their communities.

Fishing does attract [tourists] because they walk down the hill and some of them, most of them, are probably overwhelmed that there is actually fishing boats working, you see them going in an out with the tractor, the men walking round and the lorry comin' with the crabs going on it, and I take them for boat trips in the summer and I always ask them, I sort of do my own survey in my head. And they always say to me you just don't know what you've got, don't ever change it, don't ever let it be changed and of course that's what we're up against all the time. Not those sort of people changing it but fighting the government to keep it going as it is ( $\left.\mathrm{N}_{7}-\mathrm{Newlyn}\right)$.

Inshore fishing has an important role because it is generally possible for people to gain close access to fishing activity. Tourism managers often describe fishing as being 'iconic' of an area - featuring it in the publicity for a resort - and adding to its attraction whilst people are visiting.

We found that inshore fishing is of direct economic importance to the households of those who make their living fishing. There is a wider community reliance on the fishing industry for how it valorises the characteristics of an area and puts it on the map for seaside tourism. This is linked to how local people value fishing as an activity that reflects the traditions of their community, that fishermen represent authentic aspects of the area and is in turn part of how local people create their sense of community. Generally the direct impacts of inshore fishing are social and cultural for most of the community. There can be greater 
economic impacts when the catch is tied in with the cultural and social offer a resort makes to tourists. The diversity of routes that fish take to the market place and the indirect but valued role it plays in the community confound easy generalisations.

The interviews with national and regional tourism managers pointed to an awareness of the potential for developing 'local' fish: "Provenance of food is so very important - local food in $\mathrm{B} \& \mathrm{Bs}$, local fish in restaurants; this is what people want" (NT4). Although views as to the importance of fishing varied, with those in the North of England discounting it: "Fishing is a minor part of the economy...tourism is very important" (NT 5), whilst those working the South West argued that, "There is a huge heritage associated with the industry" (NT6), and that "People like going to see fishing ports...and is very much an 'added value' part of the tourism industry" (NT6). Yet one tourism manager thought that links between the sectors were scant: "We [tourism] are the 'candy floss' industry - whereas the fishing [industry] is the last of hunter gatherers" $\left(\mathrm{NT}_{7}\right)$. As we noted above, the concentration of inshore boats, and to a degree commercial fishing, in England is in the South West peninsula, as is seaside tourism. In 2009 fishing both inshore and deep water employed 6,209 people directly in England and Wales [25]. Tourism is not evenly distributed with approximately 61,ooo jobs in the 2006/8 period in the South West, 46,0oo in the South East, 29,00o in the North West but only 7,00o in the North East [11]. In this it broadly mirrors the geographic distribution of the inshore fishing sector. At a county level, in 2007 estimates for the gross value added to county economies by seaside tourism ranged from $£ 250$ million for Cornwall (Padstow and Newlyn), down to £20 million in Cumbria (Whitehaven) and £10 million in Northumberland (Amble)[11]. These figures suggested the varied importance of tourism to coastal communities in England.

\section{Discussion and conclusions}

Commercial fishing is a marginal activity in England, both economically and politically, with the inshore sector being viewed as generally less important as it is not as economically viable as the deepwater fleet. Our findings show that while inshore fishing is not defended as a vital part of the local economy, local people value it for its social and cultural contribution to the community. In part this stems from a view that fishing creates a sense 
of place that is valued as part of the creation of self and community identity by resident, with an awareness that this identity is, in part, traded upon in the creation of seaside tourism [31]. Fishing is therefore seen as both expressive and instrumental, with tourism viewed as both being an imposition and an opportunity. Fishermen are seen by others in the community as being in many ways 'authentic' locals, and are viewed sympathetically without any detailed knowledge of the fishing industry or of fishermen. Those who fish for a living are largely concerned about their occupational identity [32, 33]. Like Just and Ota we did not find generalised evidence of the inter and intra generational fishing families of much of the previous academic literature, but a more open occupational group focused on the pursuit of their way of life, success in which is not primarily defined by financial success $[34,35]$. Within their occupation many fishermen have wide ranging social networks, using the links created by mobile boats, previous work on larger vessels, radio and increasing internet contacts. Thus, whilst they may be localised they can also be surprisingly cosmopolitan.

The matrix of ecological, quota and market opportunities have seen many fishermen selling their catch through routes that provide an income but do not present the wider opportunities identified for local or certified products. Local sales and branding would appear to be an opportunity but at present there are a range of barriers from harbour regulations through to investment - with rural development programmes specifically barred from promoting sea fish - and implicitly this covers some of the activities of the local food promotion teams, such as the Rural Development Programme England (RDPE). This leaves the funds used for promoting tourism as the last best hope for promoting fish with provenance.

The problems in promoting inshore fishing in part stem from the way in which markets are supposed to operate, the forms of governance deployed and a social misunderstanding of fishermen. Taking each in turn, the irony of British fish eating is that as well as being dominated by three species the majority of sales are through multiple retailers who have been keen adopters of certification schemes - which have not often included domestic inshore fishermen. Inshore English fishermen reported that they were reluctant to invest in certification as they were uncertain as to its efficacy. A prominent representative of one certified fishery reported that their project had foundered for lack of quota. While most of 
the British food system is in large part regulated by the standard setting and certification schemes of the multiple retailers, much of domestic fish catching and processing is removed from this system, forcing it toward Continental markets and generally beyond the reach of any conservation schemes bar those implemented by the state. The regulations and systems of governance are calibrated to provide fish as an undifferentiated commodity, whilst the mass retailing of fish has passed beyond this to fish that exhibits at least third party verification of its conservation status.

Tied to this is a system of governance that attempts to manage the population of fish, a common resource, to which fishermen are only given a quota as a form of access. These quotas are derived through population modelling of fish stocks, a science that is open to contestation and dispute, whilst the final agreement on Total Allowable Catch (TAC) is conducted through a political process. Modelling in this instance would appear to be a top down process in which the expert knowledge of fishermen is largely excluded. This is particularly salient regarding fishermen operating smaller vessels who tend to fish the same grounds rather than the more nomadic larger vessels. Individual Transferrable Quotas (ITQs) are supposed to relieve this impasse, as the fishermen will be given quotas of the stock, not just a seasonal allocation providing them with a stake in the future of the population or a short term opportunity to harvest fish.

Fishermen are socially distinct in that a proxy measure manages their industry and way of life; managing fish populations has become a way of governing humans. This technocratic management creates resentment within the networks of fishermen through enforced practices such as discarding. Ironically, with their marginal economic status the community around them views fishermen as being authentic locals and embodying many of the values the wider community would want to associate with itself. Fishermen are intermediaries working with part of the land (the harbour/beach) and the sea that in ways make these coastal communities unique. Their activities such as working with the tides, working on the harbourside and tackling the elements are the activities that very publicly recreate the uniqueness of the place, part of what Jones describes as 'tidal material cultures' [36]. As they lack the overt capital or assets of, for example, many farmers, or the 'featherbedding' of which many agricultural businesses are viewed as receiving, they are frequently seen as working people receiving little help from the state. 
At the level of supra and national policy of the three legs of sustainability, the environmental and the economic have been broadly prioritised over the social in fishing policy, as Symes and Phillipson have argued [4]. In part this reflects the political power of conservation and industry lobby groups but also the epistemology on which much of fishing policy is founded. As with arguments from Beddington and colleagues at the beginning of this paper, biological models of fish populations are merged with economic ones to produce results that look to measures that privatise common resources as a reform of state driven measures. Inshore fishing has become located between the flows of power and influence around creating a 'sustainable' market for fish, projects for creating local terrestrial food products and the state's efforts at conservation. Those people in closest proximity to the industry value it for the role it plays in creating a sense of place, an identity that publicly performs an intimate and on-going relationship with the nature of a particular place.

In this mesh of powerful flows there are possibilities of resisting both the tides of the multiple retailers, and the policy lacunas of the CFP to create sustainable fisheries. It would seem that in valuing the localness of fish, there is an opportunity to build the linkages between inshore fishing and tourism following the model of the Slow Food movement [37]. In contrast to the ubiquity, robustness and blandness of global fish, the inshore fishing communities of England need to celebrate what is particular, seasonal and tasty about their catch. It needs to find a popular gastronomy that links the fish to the locality and retains an enhanced value from the catch in that locality. As part of this these models of community development will need to re-insert measures of local democratic control, to begin the dialogues that may lead towards a new governance of our shared resources. Many have commented on the lack of democracy in fishing policy [38] and the importance of creating food systems with democracy at their core [39], there are glimmers of a more accountable future for fishing in the communities on the English coastline.

\section{Acknowledgements:}

The authors would like to thank Defra's Sustainable Access to Inshore Fisheries (SAIF) team for their financial support of this project; the opinions expressed here are those of the authors and not those of Defra. We would also like to thank all of the individuals and communities who collaborated in this research project and the wider research team who 
work on the project, namely John Powell Owain Jones, Nick Lewis and Becky Griffiths.

Finally, we would like to thank the helpful and constructive peer-reviewers who contributed their thoughts to the development of this paper. 


\section{Bibliography}

[1] Canguilhem G. A Vital Rationalist. New York: Zone Books; 1994.

[2] Foucault M. Michel Foucault essential works of Foucault 1954-1984: volume 1 - ethics. London: Penguin; 1997.

[3] Beddington JR, Agnew DJ, Clark CW. Current Problems in the Management of Marine Fisheries. Science. 2007;316:1713-6.

[4] Symes D, Phillipson J. Whatever became of social objectives in fisheries policy?

Fisheries Research. 2009;95:1-5.

[5] Census of Marine Life. FIRST CENSUS OF MARINE LIFE 2010: HIGHLIGHTS OF A DECADE OF DISCOVERY. Washington: Census of Marine Life International Secretariat Consortium for Ocean Leadership; 2010.

[6] Wise M. The Common Fisheries Policy of the European Community. London: Methuen; 1984.

[7] Urquhart J, Acott T, Reed M, Courtney P. Setting an agenda for social science research in fisheries policy in Northern Europe. Fisheries Research. 2011;108.

[8] Morgan K, Marsden T, Murdoch J. Worlds of Food. Place, Power and Provenance in the Food Chain. London: Sage; 2006.

[9] Marsden T, Flynn A, Harrison M. Consuming Interests: The Social Provision of Food. London: UCL Press; 1999.

[10] Patel R. Stuffed and Starved. Markets, Power and the HIdden Battle for the World's Food System. London: Portobello; 2007.

[11] Busch L. Can Fairy Tales Come True? The Surprising Story of Neoliberalism and World Agriculture. Sociologia Ruralis. 2010;50:331-51.

[12] Loconto A, Busch L. Standards, techno-economic networks, and playing fields: Performing the global market economy. Review of International Political Economy. 2010;17:507 - 36.

[13] Bjarnason T, Thorlindsson T. Should I stay or should I go? Migration expectations among youth in Icelandic fishing and farming communities. Journal of Rural Studies. 2006;22:290-300.

[14] Shucksmith M. Inequality, power and injustice in rural areas: beyond social exclusion? . In: Paper K, editor. XXIV Congress of the European Society for Rural Sociology. Chania, Crete2011.

[15] Friedman $\mathrm{H}$. The Political Economy of Food: A global crisis? New Left Review. 1993;197:29-49?

[16] Reed M. Rebels for the Soil - The Rise of the Global Organic Movement: Earthscan; 2010.

[17] Seyfang G. Ecological Citizenship and sustainable consumption: Examining local organic food networks. Journal of Rural Studies. 2006;22:383-95.

[18] Renting H, Marsden T, Banks J. Understanding alternative food networks: exploring the role of short food supply chains in rural development. Environ Plan A. 2003;35:393411.

[19] Kirwan J. Alternative Strategies in the UK Agro-Food System: Interrogating the Alteriety of Farmers' Markets. Sociologia Ruralis. 2004;44:395-415.

[20] Brunori G, Rossi A. Synergy and coherence through collective action: Some insights from wine routes in Tuscany. Sociologia Ruralis. 2000;40:409-+.

[21] Morgan SL, Marsden T, Miele M, Morley A. Agricultural multifunctionality and farmers' entrepreneurial skills: A study of Tuscan and Welsh farmers. Journal of Rural Studies.

2010;26:116-29. 
[22] Lobley M, Butler A, Courtney P, Ilbery B, Kirwan J, Maye D, et al. Analysis of socioeconomic aspects of local and national organic farming markets. London: Defra, ; 2009. p. 226.

[23] marine management organisation. UK SEA FISHERIES STATISTICS 2009. In: Irwin C, Thomas B, editors. Newport: marine management organisation and Office of National Statistics; 2010. p. 120.

[24] Ilbery B, Kneafsey M. Producer constructions of quality in regional speciality food production: a case study from South West England. Journal of Rural Studies. 2000;16:21730.

[25] King BG, Pearce N, A. The Contentiousness of Markets: Politics, Social Movements, and Institutional Change in Markets. Annu Rev Sociol. 2010;36:249-67.

[26] Michelleti M, Stolle D. Mobilizing Consumers to Take Responsibility for Global Social Justic. The Annals of the American Academy of Political and Social Science.

2007;611:157-75.

[27] Rubin HJ, Rubin IS. Qualitative Interviewing - The Art of Hearing Data. 2nd ed. London: Sage; 2005.

[28] Yin RK. Case Study Research, Design and Methods. Second ed. London: Sage; 1994.

[29] Thurnell-Read T, Parker A. Men, masculinities and firefighting: Occupational identity, shop-floor culture and

organisational change Emotion, Space and Society. 2008;1:127-34.

[30] Schiffrin D. Jewish argument as sociability. Langauge in Society. 1984;13:311-35.

[31] Brookfield K, Gray T, Hatchard J. The concept of fisheries-dependent communities. A comparative analysis of four UK case studies: Shetland, Peterhead, North Shields and Lowestoft. Fisheries Research. 2004;75:55-69.

[32] Nutall M. Crisis, Risk and Deskilment in North-east Scotland's Fishing Industry. In: Symes D, editor. Fisheries Dependent Regions. London: Oxford; 2000. p. 106-15.

[33] van Ginkel R. Inshore Fishermen: Cultural Dimensions of a Maritime Occupation. In: Symes D, Phillipson J, editors. Inshore Fisheries Management. London: Kluwer Academic Publishers; 2001. p. 177-94.

[34] Ota Y, Just R. Fleet sizes, fishing effort and the 'hidden' factors behind statistics: An anthropological study of small-scale fisheries in UK. Marine Policy. 2008;32:301-8.

[35] Nadel-Klein J. Granny baited the lines - Perpetual crisis and the changing role of women in Scottish fishing communities. Women's Studies International Forum.

2000;23:363-72.

[36] Jones O. 'The Breath of the Moon': The Rhythmic and Affective Time-spaces of UK Tides. In: Edensor T, editor. Geographies of Rhythm: Nature, Place, Mobilities and Bodies. Farnham: Ashgate; 2010.

[37] Petrini C, Padovani G. Slow Food Revolution. A new culture for eating and living. New York: Rizzoli; 2006.

[38] Griffin L. The limits to good governance and the state of exception: A case study of North Sea fisheries. Geoforum. 2010;41:282-92.

[39] Lang TIM. Crisis? What Crisis? The Normality of the Current Food Crisis. Journal of Agrarian Change. 2010;10:87-97.

[40] Reed M, Courtney P, Dwyer J, Griffiths B, Jones O, Lewis N, et al. The Social Impacts of England's Inshore Fishing Industry: Final Report. London: DEFRA; 2011. p. 75.

[41] Beatty C, Fothergill S, Gore T, Wilson I. The seaside tourist industry in England and Wales. Sheffield: Centre for Regional Economic and Social Research; 2010. 
Figure 1: Map of case studies on the English coast. 
List of Tables and Figures

Table 1: Figures supporting selection of case studies

Table 2: Number and categories of interviewees by case study

Table 3 - Description of the case study communities 


\begin{tabular}{|c|c|c|c|c|c|c|c|}
\hline $\begin{array}{l}\text { Port } \\
\text { name }\end{array}$ & County & Pop'n & $\begin{array}{l}\text { Fishing } \\
\text { income } \\
\text { /Income per } \\
\text { capita } 2003\end{array}$ & $\begin{array}{l}\text { Numbe } \\
\text { r of } \\
\text { under } \\
\text { lom } \\
\text { boats }\end{array}$ & $\begin{array}{l}\text { Boats } \\
\text { registered } \\
\text { / Boats per } \\
\text { capita } \\
\left({ }^{*} 100\right) 2009\end{array}$ & $\begin{array}{l}\text { Under } \\
\text { 1om } \\
\text { as } \% \\
\text { of all } \\
\text { boats }\end{array}$ & $\begin{array}{l}\text { IMD } \\
\text { ranki } \\
\text { ng } \\
2007\end{array}$ \\
\hline Newlyn & S. Cornwall & 2687 & $\begin{array}{l}£ 17.7 \mathrm{~m} / \\
£ 6,570\end{array}$ & 88 & $140 / 5.21$ & $63 \%$ & 3709 \\
\hline Padstow & N. Cornwall & 2449 & $£ 1.7 \mathrm{~m} / £ 713$ & 13 & $18 / 0.74$ & $72 \%$ & 12,267 \\
\hline Whitby & $\begin{array}{l}\text { North } \\
\text { Yorkshire }\end{array}$ & 13594 & $£ 2.7 \mathrm{~m} / £ 196$ & 20 & $34 / 0.25$ & $59 \%$ & 8176 \\
\hline Amble & Northumberland & 6044 & $£ 1.2 \mathrm{~m} / £ 196$ & 22 & $30 / 0.50$ & $73 \%$ & 22,349 \\
\hline Rye & $\begin{array}{l}\text { East } \\
\text { Sussex }\end{array}$ & 4195 & $£ 0.7 \mathrm{~m} / £ 170$ & 25 & $27 / 0.64$ & $93 \%$ & 21,991 \\
\hline $\begin{array}{l}\text { Whitehav } \\
\text { en }\end{array}$ & Cumbria & 24978 & $£ 2.17 \mathrm{~m} / £ 87$ & 15 & $15 / 0.06$ & $100 \%$ & 11,116 \\
\hline
\end{tabular}

Table 1: Figures supporting selection of case studies

(Source: [40]) 
Table 2: Number and categories of interviewees by case study

\begin{tabular}{|l|l|l|l|l|}
\hline Case study & Fishermen & Fishing family & Allied Industry & Citizen \\
\hline Amble & 4 & 2 & 6 & 4 \\
\hline Newlyn & 4 & 1 & 6 & 7 \\
\hline Padstow & 4 & 1 & 3 & 2 \\
\hline Rye & 4 & 1 & 2 & 10 \\
\hline Whitby & 5 & 0 & 6 & 10 \\
\hline Whitehaven & 3 & 0 & 3 & 2 \\
\hline Totals & 24 & 5 & 26 & 35 \\
\hline
\end{tabular}

(Source: [25]) 
Table 3-Description of the case study communities

\begin{tabular}{|c|c|}
\hline Town Name and Location & Description \\
\hline Newlyn, Cornwall & $\begin{array}{l}\text { One of the largest commercial fishing ports on the South } \\
\text { coast of England, with } 140 \text { under 1om boats and a } \\
\text { considerable fleet of larger vessels, a cluster of fishing } \\
\text { development projects and a negligible tourism industry. }\end{array}$ \\
\hline Padstow, North Cornwall & $\begin{array}{l}\text { The town has } 18 \text { inshore boats, but as the centre of the } \\
\text { TV Chef Rick Stein’s businesses and a picturesque } \\
\text { harbour, tourism provides } 51 \% \text { of the employment in the } \\
\text { town worth approximately } £ 17 \text { million annually to the } \\
\text { town's economy annually [41]. }\end{array}$ \\
\hline Rye, Sussex & $\begin{array}{l}\text { An estuarine port with } 27 \text { under } 10 \mathrm{~m} \text { boats, an increase } \\
\text { in the last decade built on a trade of scallops in } \\
\text { particular, although tourism is the most important } \\
\text { industry in the town }\end{array}$ \\
\hline Whitby, North Yorkshire & $\begin{array}{l}\text { The town has } 34 \text { under 10m boats, and a fishing industry } \\
\text { said to be struggling whilst much of the town's income is } \\
\text { derived from tourism ( } 24 \% \text { or 2,ooo people) [ } 41] \text {. } \\
\text { Visitors are drawn to the town by the Abbey and its } \\
\text { association with Dracula, as well as the lure of fish and } \\
\text { chips }\end{array}$ \\
\hline Amble, Northumbria & $\begin{array}{l}\text { The town has } 29 \text { registered boats, a fish processing } \\
\text { factory and a small tourism industry ( } 15 \% \text { of } \\
\text { employment in the town)[41]. Fishing is the last of the } \\
\text { traditional industries remaining in the area following } \\
\text { the demise of mining. }\end{array}$ \\
\hline Whitehaven, Cumbria & $\begin{array}{l}\text { The town has only } 15 \text { under 1om boats in the renovated } \\
\text { harbour that was once a major entrepôt for transatlantic } \\
\text { trade and industrial goods, now overtaken by energy } \\
\text { generation, both nuclear and wind powered }\end{array}$ \\
\hline
\end{tabular}

